\title{
Charismatic Leadership Impact on Employee Psychological Engagement: Evidence from Travel Companies
}

\begin{abstract}
Azza Maher*
*Tourism Studies Department, University of Sadat City

\section{Abstract}

Researchers in organizational behavior have long been interested in exploring how employees' perceptions of their leaders influence their work-related thoughts and behaviors. The present study examines the effect of charismatic leadership style on employee psychological engagement in travel companies. The study data is collected using questionnaires completed by 339 employees working in travel companies. The questionnaires have been designed based on the Conger Kanungo model to measure charismatic leadership behavior and the Utrecht Work Engagement Scale (UWES) to assess employee psychological engagement. The results of this study indicate that charismatic leadership is positively related to employee psychological engagement $(p<0.05)$. Moreover, a significant predictive relationship $(\mathrm{p}<0.05)$ is found between charismatic leadership style and employee psychological engagement, with variability of $54.9 \%$. The results also reveal that managers with high "sensitivity to member needs" (SMN) have effective impact on improving employee psychological engagement. In addition, the results demonstrate that "absorption" is the most associated subscale that could be predicted by charismatic leadership. Finally, this study discusses managerial implications of results, introduces recommendations, and presents suggestions for future research.
\end{abstract}

Keywords: Charismatic leadership, charisma, followers, employee psychological engagement.

\section{Introduction}

Leadership is an important concept not only in the social sciences, but also in corporate life. Scientists as well as managers are eager to know what makes an effective leader. Leaders need to shape a culture that promotes realization of a company's goals and objectives. These are behaviors that are associated with charismatic leadership style. According to Flynn and Staw (2004:309), the term "charismatic leadership" has been used to describe a subset of leaders who "by the force of their personal abilities are capable of having profound and extraordinary effects on followers".

In the last decade, there has been also a great attention paid to the concept of employee psychological engagement. A number of researchers have declared that employee engagement can be used as an indicator of the outcomes achieved by employees, success of the organization, and level of financial performance (e.g. total shareholder return) (Bates, 2004; Baumruk, 2004; Richman, 2006; Saks, 2006). Catlette and Hadden (2001) define employee engagement as the positive and effective psychological work-related state of mind that encourages employees to actively express and invest themselves emotionally, cognitively, and physically in their job. 
Engaged employees work harder; and they are more likely to go above the requirements and expectations of their work (Lockwood, 2007). Recently, employee engagement has been considered as a modern organizational psychological trend; however, more academic research is still needed on it, especially in tourism management. Obviously, only practitioner literature and consulting firms are the main sources of information regarding employee psychological engagement (Saks, 2006). As a result, due to the lack of knowledge about this term, organizations are unaware of the critical strategies necessary to measure and promote employee psychological engagement (Czarnowsky 2008; Ghadi et al., 2010).

According to Lockwood (2007), the main factor that influences employee psychological engagement and commitment is the manager-employee relationship. She emphasizes that the manager creates the connection between the employee and the organization, and as a result, the manager-employee relationship is often recognized as the "deal breaker". Moreover, Ul Haq et al., (2016) state that organizations have to engage employees in their work and in good behaviors that are beneficial for both the employees and the organization by providing the different styles of leadership. Charismatic leadership is the most effective style for engaging employees in their work (Meredith et al., 2010; Strickland et al., 2007). In addition, previous research has found that charismatic leadership is positively associated with work engagement (Strickland et al., 2007). Roberson and Strickland (2010) also have concluded that charismatic leaders can spark employees' engagement in work, which can lead to participation in positive behaviors that promote the organization.

On the other hand, Bakker and Bal (2011) argue that the role of the leader in fostering work engagement has received limited research attention. In other words, there remains a gap in understanding how leadership behaviors could affect engagement-encouraging cultures as well as the processes around which leader behaviors bring about higher levels of engagement, which is in line with the more drastic argument that there is no research directly linking leader behaviors and follower engagement (Xu and Thomas, 2011; Carasco-Saul et al., 2015) More specifically, there has been no empirical work explicitly linking charismatic leadership and the mechanisms through which it can affect work engagement (Roberson and Strickland ,2010).

Due to the previous reasons and by examining the current literature that has studied the relationship between charismatic leadership and employee psychological engagement, this study attempts to fill the aforementioned knowledge gap and add to the understanding of employee behavior and workplace energy within the framework of charismatic leadership theory in the tourism industry. This research also contributes to the field of organizational psychology by adding more evidence that charismatic leadership is associated with improving employee performance through employee psychological engagement. This study can provide more insight into the possible effects of management, more specifically, with regard to managers who exhibit charismatic leadership qualities. 
In addition, the present research can be a foundation for future interventions that foster charismatic leadership and work engagement to increase productivity in tourism organizations. Combined with future research, this study could have significant implications for the hiring and training of leaders within travel companies. With this aim in mind, this study attempts to:

1- Investigate the relationship between charismatic leadership style and employee psychological engagement in the tourism sector (travel companies).

2- Determine whether there is any predictive relationship between charismatic leadership style and employee psychological engagement.

3- Identify which subscales of employee psychological engagement are more associated with and could be predicted by charismatic leadership.

\section{Theoretical Background}

\subsection{Charismatic Leadership Theory}

The concept of charisma was first introduced by Weber in1947. He considered charisma a gift "of the body and spirit not accessible to everybody" ( Antonakis et al. 2011: 375). Historically, the term charisma is derived from an ancient Greek word meaning "gift" (Conger et al., 1997; Hayibor, 2011; Forsstrom, 2012; Fletcher and Robinson, 2014). Later, the early Christian Church used the word "charisma" to refer to gifts or charismata from God that gave the receiver the power to heal or prophesy (Forsstrom, 2012, Fletcher and Robinson, 2014). Nowadays, the term is commonly used to describe political and organizational leaders (Findiklia et al., 2012). Ul Haq et al. (2016) have stated that Charisma is an optimistic and persuasive trait that enables the individual to lead others. Also, the charismatic leader has extraordinary powers distinguishing him (Jacobsen and House 2001; Kaul, 2013).

Cicero and Pierro (2007) have stated that the model of charismatic leadership has been developed within organizational settings (Conger and Kanungo, 1987, 1998; House and Shamir, 1993; House, 1999). Moreover, how followers perceive their leaders' behavior is one of the pillars of this model. Charismatic leaders give the impression they are phenomenal and their goals are exceptional through inspirational visions and behaviors. The followers believe in their leaders' outstanding character rather than their position (Cicero and Pierro, 2007). Nandal and Krishnan (2000) have argued that charisma emerges from a mix of emotional attitude, self-confidence, self-determination, and internal peace. Shao et al. (2009) have stated that the charismatic leadership theory is a reliable approach to understand successful leadership (Hughes and Ginnett, 2003;Bryman, 2004; Shalley and Gilson, 2004). Obviously, the charismatic leadership theory has developed over the years (Koene and Vogelaar, 2002; Tosi et al., 2004; Waldman and Javidan, 2004; Susan and Ellen, 2008).

The original charismatic leadership theory by Weber (1947) describes how followers believe in leaders' extraordinary qualities (charisma). Recently, this theory has been modified and expanded to define charismatic leadership in formal organizations (Conger, 1989; Shamir et al., 1993; Conger and Kanungo, 1998; House, 1999;). 
Moreover, a number of researchers state that "charisma" is a component of transformational leadership. Thus, the terms of transformational and charismatic leadership are used interchangeably in the organizational literature (Conger and Kanungo, 1994).

The charismatic leadership theories are mainly concerned with the relationship between the leader and his followers and with his influence on them (Zehir et al., 2011). However, such theories differ according to the core behaviors in charismatic leadership. This sometimes appears in the older and newer versions of the same theory .For example , Conger and Kanungo in 1987 have developed a model of charismatic leadership within organizations that introduces behavioral dimensions in three definite stages of the leadership process (Nandal and Krishnan, 2000). The first stage (the environmental assessment stage) explains environmental opportunities, constraints, and followers' needs via the status quo. In the second stage (the vision formulation stage), charismatic leadership is characterized by the followers' perception of the manager's formulation of a flawless future vision that they are part of it; and the followers are inspired by the leader's effective delivery of this vision. In the third stage (the implementation stage), charismatic managers provide a leadership example to their followers (Conger and Kanungo, 1992; Conger et al., 2000; Nandal and Krishnan, 2000). Another study was conducted by Shao et al., (2009) has investigated charismatic leadership based on five dimensions: Environmental sensitivity, dynamic leadership, exemplary leadership, personal leadership, and leader expectations . The description of these five dimensions is shown in Table 1 .

Table 1. Five Dimensions of Charismatic Leadership

\begin{tabular}{|l|l|l|}
\hline \multicolumn{1}{|c|}{$\begin{array}{c}\text { Charismatic } \\
\text { leadership }\end{array}$} & Five dimensions & \multicolumn{1}{|c|}{ Description } \\
\cline { 2 - 3 } $\begin{array}{l}\text { Environmental } \\
\text { sensitivity }\end{array}$ & $\begin{array}{l}\text { Leader's ability to make timely decision to } \\
\text { apply to organizational environmental change }\end{array}$ \\
\cline { 2 - 3 } $\begin{array}{l}\text { Dynamic } \\
\text { leadership }\end{array}$ & $\begin{array}{l}\text { Leader's ability to communicate an exciting } \\
\text { vision and paint an exciting picture of the } \\
\text { future of the organization }\end{array}$ \\
\cline { 2 - 3 } & $\begin{array}{l}\text { Exemplary } \\
\text { leadership }\end{array}$ & $\begin{array}{l}\text { Leader's ability to set a good example to his } \\
\text { employees through participating in } \\
\text { organizational activities }\end{array}$ \\
\cline { 2 - 3 } & $\begin{array}{l}\text { Personal } \\
\text { leadership }\end{array}$ & $\begin{array}{l}\text { Leader's ability to encourage his employees } \\
\text { and improve their self-confidence }\end{array}$ \\
\cline { 2 - 3 } & $\begin{array}{l}\text { Leader } \\
\text { expectation }\end{array}$ & $\begin{array}{l}\text { Leader's ability to create lofty expectations } \\
\text { for his employees and empower them }\end{array}$ \\
\hline
\end{tabular}

Source: Shao et al., (2009:3) 
Moreover, Findikli and Yozgat (2012) have added another dimension (a sixth dimension) to charismatic leadership. This dimension is "risk undertaking". It refers to the leader's skill with regard to undertaking necessary risk in order to initialize organizational change. After charismatic leaders evaluate environmental risks and opportunities, they develop a vision followed by interaction with members of the organizations. However, in case the specified mission is different from the existing vision of the corporate, the charismatic leader undertakes risks by deviating from the status quo. During this process leaders consider the members' requirements and expectations in order to guarantee their support when needed (Conger, 1998).

In addition, Tilstra (2010) has explained charismatic leadership as a process through which a particular relationship is created and maintained between the leader and the followers. The leader offers an intellectually stimulating vision of a preferred future, expresses high expectations and confidence in the followers, and models behavior that contributes toward the creation of the preferred future. In order for a charismatic relationship to be formed, the followers must respond by accepting the leader's vision and committing themselves to it. If the followers do not respond, there is no charismatic leadership (Howell and Shamir, 2005; Susan and Ellen, 2008).

Based on the above mentioned, Ehrhart and Klein (2001) have summarized the findings of Conger et al. (1997-2000), House and Howell (1992), and Shamir et al. (1993) in a four-point definition of charismatic leadership. These works suggested that the charismatic leader should be able to: (a) Communicate high performance expectations to followers; (b) exhibit confidence in followers' ability to reach goals; (c) take calculated risks that oppose the status quo and (d) articulate a value-based overarching vision and collective identity.

In order to stress its value, House (1997) cites the positive effect of charismatic leaders in organizations. His findings indicate that charismatic leaders receive higher performance ratings, have more satisfied and more highly motivated followers, and are viewed as more effective leaders by their superiors and followers than others in positions of leadership. Furthermore, Conger and Kanungo's findings (1994) indicate that charismatic leaders are especially effective at innovation and helping organizations move beyond ineffective status quo attitudes and behavior. Birchfield (2000) has considered charisma and vision separate and independent components of leadership. He notes that when charismatic leaders combine charisma with vision, they tend to have motivated, committed, and high-performing followers. On the other hand, some researchers question the potential positive contributions of charismatic leaders. Raelin (2003) has described charismatic leaders as grandiose, brutally exploitive, and self-promoters with a savior complex. He dismisses the need for charismatic leaders as a mere myth. Khurana (2002) observes that the positive effect of charismatic leaders is exaggerated and, in fact, they tend to destabilize organizations. 


\subsection{Charismatic Leaders}

According to Poskas et al. (2013), charismatic leaders are defined as individuals who obtain "a gift of grace." Charismatic leaders are highly recognized for their visionary qualities and qualities that are important in crisis situations and their ability to engage others in action. Furthermore, Weber in 1947 was the first researcher used the term charismatic leader; he has defined charismatic leaders as people with extraordinary qualities; he considers them as heroes. People high in charisma are believed to be endowed with supernatural or exceptional powers (Ricketts, 2009; Poskas et al., 2013).

According to Roberson and Strickland (2010), charismatic leaders influence and inspire their subordinates, clarify ambiguous situations, handle drawbacks, and provide a strategic vision that motivates positive thinking for the future and for change (Ehrhart and Klein, 2001; Jacobsen and House, 2001; Paulsen et al., 2009 and Shao et al., 2009). In addition, charismatic leaders communicate high performance expectations, show confidence in their followers' abilities and emphasize a collective identity (Shamir, 1998; Ehrhart and Klein, 2001; Jacobsen and House, 2001; Roberson and Strickland, 2010).

Charismatic leaders also make personal sacrifices and they are considered as role models whose attitudes and behaviors encourage members to believe in themselves to overcome problems (Yorges et al., 1999; Jacobsen and House, 2001, Takala, 2007; Findikli et al., 2012). Moreover, while helping their members develop their problem solving skills, charismatic leaders simultaneously support team work (Basadur, 2004).

In addition, Findikli et al. (2012) have revealed that charismatic leaders are capable of identifying members' requirements, values, sources, and expectations correctly, thereby transforming them into collective interests and making members become voluntarily committed to their leaders' missions. In other words, charismatic leaders can capture members' feelings and establish necessary integration within the group (Susan and Ellen, 2008). The interaction between leaders and members has resulted in an increase in group motivation and work satisfaction in corporations (Susan and Ellen, 2008; and Findikli et al., 2012). Therefore, a charismatic leader's positive impact on his group creates an environment that fosters innovative ideas (Amabile, 2004; Susan and Ellen, 2008).

Paulsen et al., (2009) have found out as a result of their research about the influence of charismatic leadership behavior on innovation at the research and development (RandD) corporations that charismatic leaders' behavior supports innovation. Moreover, it has been realized that providing suitable training contributes to acquiring self-confidence and developing creative thinking skills and transforming those skills into creative performances (Takala, 2007; Findikli et al., 2012). Through providing trainings and rewards, leaders indirectly help members develop personal creativeness (Shalley, and Gilson,2004). 
Many studies have utilized the leadership theory to investigate leadershiprelated phenomena in hospitality and tourisms contexts. There has been a broad range of approaches taken and a wide range of findings i.e. Susskind et al., 2000a; Susskind et al., 2000b; Testa, 2004; Tutuncu and Kozak, 2007; Chiang and Jang, 2008; Deery, 2008; Øgaard et al., 2008; Tsai, 2008; Clark et al., 2009; Kuruüzüm et al., 2009; Yang, 2010; Boyen, 2012; Babaita et al., 2013; Poskas and Messer, 2015.

\subsection{Employee psychological engagement}

Organizations are concerned with how employees think and feel about their jobs and what employees are willing to introduce to their organizations. Researchers have argued that when employees are engaged in the organization, they are motivated to achieve high levels of job performance and customer satisfaction (Kahn, 1990; Rich, et al., 2010; Christian et al, 2011; George and Joseph, 2017; Gupta et al., 2015, Zainol et al., 2016). Employee psychological engagement is a motivational concept that can be also shared by employees in the workplace to perform the assigned task. (Christian et al., 2011; Findikli et al., 2012). Generally, engagement is a positive state of mind that reflects the level of employee's satisfaction, pride in, and commitment and connection with his job and organization. Therefore, employee loyalty is based on employee psychological engagement (Christoffer, 2004; Bakker and Demerouti, 2008). Employee engagement is measured by the degree of employees' satisfaction and involvement to achieve business success. It also leads to improvements, increases productivity, and reduces employee turnover (Roberson and Strickland,2010).

Kahn's conceptual work is considered the base for the development of the theoretical framework of employee engagement. Employee engagement is a multidimensional concept (Kahn, 1990). He has formally defined engagement as "the simultaneous employment and expression of a person's preferred self in task behaviors that promote connections to work and to others, personal presence (physical, cognitive, emotional) and active, full performances". (Roberson and Strickland, 2010:60)

Rothbard (2001: 656) also defines engagement as "psychological presence". He adds that it includes two main components: Attention and absorption. Attention refers to "cognitive availability and the amount of time one spends thinking about a role", while absorption means "being engrossed in a role" and refers to "the intensity of one's focus on a role" (Saks, 2006). Moreover, Sharmila (2013) has defined employee psychological engagement as the employees' positive attitude or commitment to the organization and its value.

In addition, May et al., (2004) have attempted to conceptualize work engagement and define it through three components: First, there is the physical component, which refers to the effort done to perform the job. Second, there is the emotional component, which is related to sacrificing for the job. Third, there is the cognitive component, which is described as being totally involved in the job. Since they think about their organization, leaders, and working conditions (Lolitha and Johnson ,2014). 
Most researchers agree on the construct of work engagement; however, different views of its conceptualization have been introduced (Bakker et al., 2008; Zehir, 2011; Ariani, 2013). In short, engaged employees are energetic and enthusiastic to the extent that time flies at work (May et al., 2004; Bakker and Demerouti, 2008). On the other hand, Soane et al., (2012) have developed a measure for employee psychological engagement consists of three dimensions: Intellectual, affective, and social (George and Joseph, 2017). Bakker and Demerouti (2008) have defined these three types of engagement: Intellectual engagement refers to the degree employees are involved in their jobs and to their belief in their ability to achieve outstanding performance. Affective engagement reflects the extent to which employees feel positive about their work and organization. Social engagement is related to employees' conversations with their social group about their work experiences and achievements (Bakker and Demerouti, 2008; Purcell, 2012).

Furthermore, work engagement is considered a positive and work-related state of mind that is characterized by vigor, dedication, and absorption (Schaufeli et al., 2002). Vigor refers to physical energy, emotional power, desire to work, and facing difficulties with a positive attitude. Dedication reflects a sense of significance, enthusiasm, inspiration, pride, and challenge. Absorption refers to the employee being completely immersed in work, disconnected from the outside world to the extent that he does not notice the passing of time (Schaufeli et al., 2002; Ghadi,2010; Roberson and Strickland, 2010; Zehir et al., 2011; Ghadi et al., 2013.).

In addition, a number of studies i.e. Chaudhary and kumar (2014); Zainol et al., ( 2016) ;George and Joseph†(2017) have been concerned with the concept of engagement in the hospitality and tourism industry. According to Sadiqe (2014) employee psychological engagement has some positive effects on the hospitality industry. Engaged employees will be loyal to their organization improving its products and service and providing a high-energy working environment. They are also emotionally attached to the guests and, consequently, customer satisfaction and customer loyalty to the organization are created.

\subsection{Charismatic Leadership and Employee psychological engagement}

By reviewing a considerable number of studies and scientific papers in human resource management, it is observed that many researchers have discussed the relationship between employee psychological engagement and other organizational attributes (Bakker et al., 2008; Bakker et al., 2011; Albrecht,2012) such as organizational citizenship behavior i.e. Ariani (2013), financial performance i.e.Saks, (2006);Xanthopoulou et al., ( 2009) and Bakker et al., (2011), job satisfaction and organizational commitment i.e.Smith and Markwick( 2009); Agyemang and Ofei, (2013); Lolitha and Johnson(2014), job resources i.e.Schaufeli and Bakker( 2004 ), job performance i.e. Halbesleben and Wheeler (2008) ;Bakker and Bal( 2010); Bakker et al., (2011), and client satisfaction i.e.Salanova et al.,( 2005)and Bakker et al., (2011). 
Obviously, both the academic and the practitioner literature highlight that leadership style has a significant influence on employee psychological engagement levels (Conger, 2000; Smith and Markwick, 2009; Roberson and Strickland, 2010; Ndethiu, 2014; Gözükara and Şimsek, 2016). Once employees are recruited into the organization, managers believe in their abilities to have a positive influence on the engagement of their staff (Smith and Markwick, 2009; Gözükara and Şimsek, 2016). Leaders are an integral part of any organization, considering that they are responsible for communicating and connecting with the employees and have the ability to motivate employees to get engaged and feel supported at work (Koppula, 2008).

According to a study by Luthans and Peterson (2002) a manager's self-efficacy can lead to increases in the engagement and effectiveness of their subordinates. Moreover, employees who have confidence in their leadership are more likely to show higher engagement than those who have low confidence level (Smith and Markwick, 2009). In the same context, this conclusion is supported by the Kenexa Research Institute (Kenexa, 2008 ).

Another study by Tims et al., (2011) has investigated whether supervisors' leadership style influences followers' daily work engagement. They have predicted that transformational leadership would enhance employees' work engagement through the mediation of self-efficacy and optimism (Smith and Markwick, 2009; Gözükara and Şimsek, 2016).

Moreover, the motivational effects of leaders can lead to more self-concept engagement of followers in their work (Bono and Judge, 2003; Roberson and Strickland,2010). Similarly, a study by Zhu et al., (2009) shows that there is a correlation between transformational leadership style and employee psychological engagement. This correlation is commonly found when the employees are active, productive, and creative (Gözükara and Şimsek, 2016). Ghadi et al., (2010) also reveal that engagement at work depends on factors such as the relationship between the employees and their managers. Briefly, employees' levels of engagement increase when there is a positive relationship between the employees and their direct supervisors (May et al., 2004; Gopal 2006;Bakker and Schaufeli, 2008).

Furthermore, charismatic leaders gain followers' admiration, trust, confidence, and respect. They also inspire their followers to pursue a higher collective goal. As a result, followers become more engaged in and enthusiastic about the common vision created by the leader (House andHowell, 1992; Schaufeli, 2002; Gözükara and Şimsek, 2016).

Based on the literature review the following hypotheses can be formulated:

Hypothesis 1. Charismatic leadership behavior of managers will enhance employee psychological engagement in travel companies.

Hypothesis 2. There is a predictive relationship between charismatic leadership style and employee psychological engagement in the travel companies. 


\section{Methodology}

Based on previous research in the areas of employee psychological engagement and charismatic leadership i.e. Schaufeli et al., (2002);Sadiqe (2004);Strickland et al., (2007); Alfes et al., ( 2010); Gözükara and Şimsek( 2016) and U1 Haq et al., 2016, the current study is designed to investigate the relationship between charismatic leadership style and employee psychological engagement in travel companies. Also, this study aims at determining whether there is any predictive relationship between charismatic leadership style and employee psychological engagement. Moreover, the present research tries to identify which dimensions of employee psychological engagement are more associated to and could be predicted by charismatic leadership.

In order to achieve the objectives of this paper, the researcher has developed a model which is used later in constructing the questionnaire. The dependent and independent variables of the study are suggested to be in a theoretical proposed model (see Figure 1). Previous literature reviews have been used as a guide to develop this model that shows the effect and relationship between charismatic leadership and employee psychological engagement in travel companies.

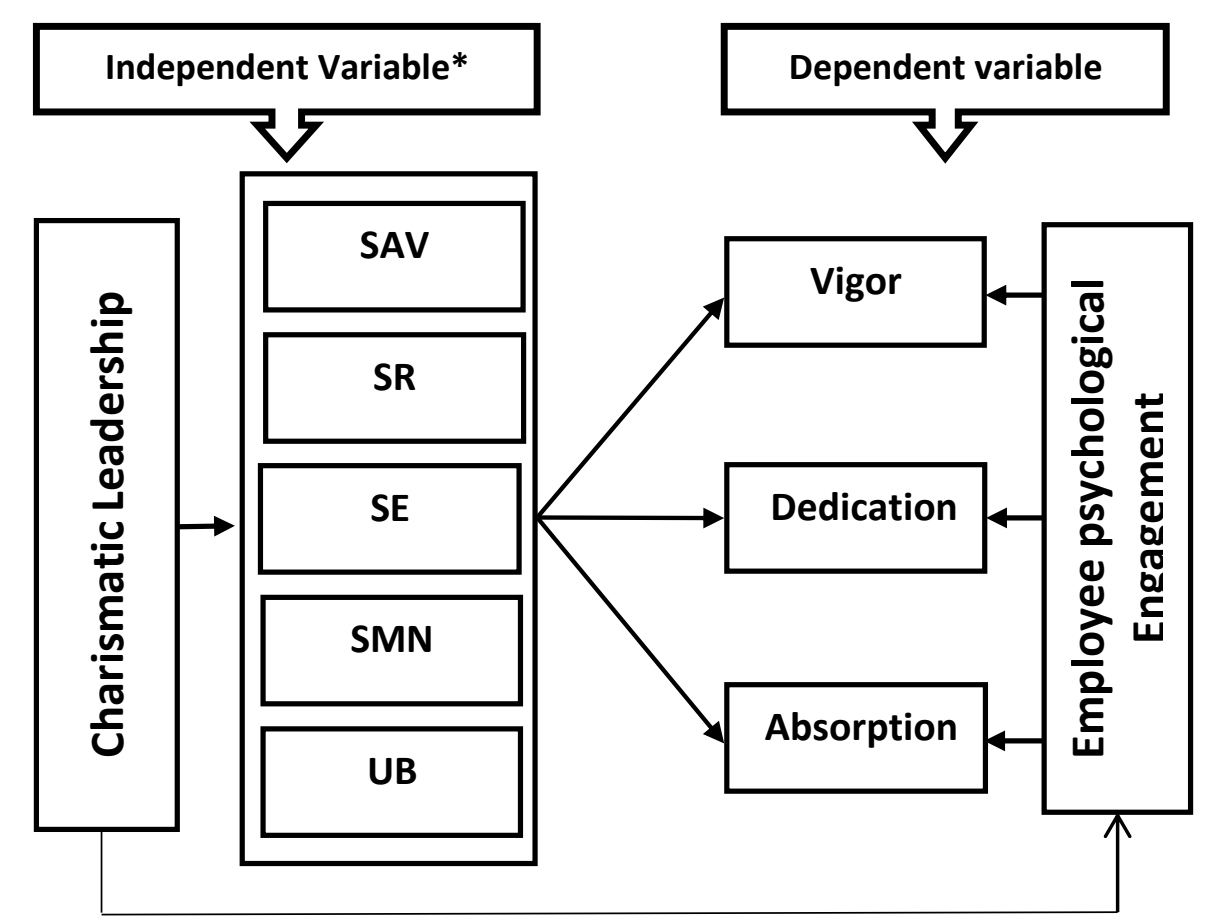

Figure 1. Proposed Model for Field Study

*Strategic vision and articulation (SVA), Personal risk (PR), Sensitivity to the environment (SE), Sensitivity to member needs (SMN), and Unconventional behavior $(U B)$

\subsection{Measuring Instruments}

The questionnaire consists of three sections: The first section has been designed to elicit demographic information about the employees. The second section consists of 20 items to measure charismatic leadership. The third section consists of 17 items to assess employee psychological engagement in tourism companies. 
The design of the questionnaire is based on the Conger Kanungo model to measure charismatic leadership behavior and on the Utrecht Work Engagement Scale (UWES) to assess employee psychological engagement. All items except the demographic information is measured on a 5-point Likert scale from "strongly disagree", (1) to "strongly agree", (5). Furthermore, the employees in the investigated travel companies have been asked to rate their managers' charismatic leadership behavior; then, they have been asked to identify their level of engagement to their companies. The following part illustrates the subscales of the two variables and the reasons for using the above mentioned models.

\subsubsection{Charismatic Leadership Behavior}

The 20-item Conger Kanungo charismatic leadership scale is used in this study to measure charismatic leadership behavior. This scale has been tested through a series of empirical studies (Conger and Kanungo, 1992, 1994; Conger et al., 1997). The results of these studies declare that the Conger Kanungo scale has strong psycho- metric properties with adequate reliability and convergent validity. The factor structure of the Conger Kanungo scale also indicates that the perceived behavioral components of charismatic leadership are stable. Finally, correlations of each of the Conger Kanungo charismatic leadership subscales with other perceived leadership behavior measures reveal that the models and the scale, as its operational measure, are different from the existing leadership scales (Conger and Kanungo, 1994). The scale includes five subscales: Strategic vision and articulation (SVA), which is assessed by 7 items; personal risk (PR), which is assessed by 3 items; sensitivity to the environment (SE), which is measured by 4 items; sensitivity to member needs (SMN), which is assessed by 3 item.; and finally the questionnaire uses 3 items to measure unconventional behavior (UB).

\subsubsection{Employee psychological engagement}

Work engagement can be measured by a number of instruments. However, in this study, an adapted version of the Utrecht Work Engagement Scale (UWES) is used to measure employee engagement (Schaufeli and Bakker, 2003). The 17-item UWES determines three underlying subscales of employee psychological engagement: Vigor, dedication, and absorption. "Vigor" is assessed by the six items that consider high levels of energy and resilience, the desire to exert effort, endurance, and facing difficulties. "Dedication" is assessed by five items that refer to realizing the importance of the work done, showing enthusiasm about and pride in the job, and feeling inspired and challenged by it. Moreover, "absorption" is measured by six items that refer to being totally and satisfactorily involved in work and disconnected from the outside world losing the sense of time passing (Schaufeli and Bakker,2004). Actually, the study depends on this scale since it is the most often used scientifically derived measure of engagement (Schaufeli et al., 2002;Schaufeliand Bakker, 2010; Bakker et al., 2011). 
Moreover, it has been considered a valid and reliable measure of the engagement construct (Bakker et al., 2011); it has been validated in several countries in Europe, North America, Africa, Asia, and Australia (Bakker, 2009). The initial questionnaires was prepared. Also, a pre-test was conducted with two identified groups for comments, 20 managers and 15 employees from Egyptian travel companies' category " $\mathrm{A}$ ". The purpose of the pre-test was to detect potential problems in the design, clarity, and wording of the questionnaire (Zikmund et al., 2013). The groups commented positively on the overall layout, instructions, and design of the questionnaire. They also had no serious problem with clarity or wording. Based on the feedback received, wording of some items has been slightly altered to match the specific context of this study.

\subsection{Population and Sampling Techniques}

The target population of this study is employees in travel companies, category "A" in Egypt. Because of the size of the population and its distribution in several governorates, this research has selected travel companies located only in Great Cairo (Cairo, Giza, and Qalubia). Furthermore, the population elements (employees) are selected on the basis of the duration of employment, since he/she must have completed at least one year in the company. As cited in Egyptian Travel Agents Association (2016), there are 1229 category "A" travel companies in Egypt that are located across the Great Cairo Governorates. First, the researcher has randomly selected 250 travel companies. The final questionnaire survey has been managed through an online survey development cloud-based software: SurveyMonkey. The questionnaire was sent and collected from April to August 2017. In total, 373 copies have been collected, 34 incomplete responses have been removed, and (339) responses from176 travel companies are used for the analysis.

\subsection{Data Analysis}

Different statistical techniques using SPSS 17 have been applied to analyze the data. The reliability analysis performed to assess the internal consistency of the measurement scales and Cronbach's alpha coefficients $(\alpha)$ of the scales have been computed. Moreover, descriptive statistics such as mean scores and standard deviations are computed for the studied variables. In addition, Spearman correlation analysis has been conducted to examine the correlations among the dimensions of charismatic leadership and employee psychological engagement. Finally, a series of regression analysis have been conducted to assess the effects of charismatic leadership on employee psychological engagement. Standardized beta is used for all of these regression analyses. Finally, statistical significance is considered less than 0.05 for $\mathrm{P}$ values.

\section{Results and Discussion}

The Cronbach's alpha coefficient has been calculated for all the constructs. It exceeds 0.70, which means that results are reliable (Hall, 2008). Table 2 lists the reliability statistics for each construct. 
The standard Alpha values for charismatic leadership and employee psychological engagement are 0.72 and 0.76 , respectively. Moreover, results from applying reliability analysis shows that the tool used is reliable.

Table 2. Variable Reliability

\begin{tabular}{|l|c|}
\hline \multicolumn{1}{|c|}{ Variables } & Cronbach's alpha (Reliability) \\
\hline Charismatic leadership & 0.72 \\
\hline Employee psychological engagement & 0.76 \\
\hline
\end{tabular}

\subsection{Respondents' Profiling}

During the investigation phase, 339 employees have been tested, $57,8 \%$ are males and $42.2 \%$ are females. Regarding the participants' age, $42.2 \%$ of the participants are less than 35 years, $29.4 \%$ are from 35 to 45 years, and only $28.4 \%$ are older than 45 years. The majority of respondents $(60.2 \%)$ have working experience between 5 to 10 years, while $23.4 \%$ have less than 5 years experience and $16.4 \%$ have more than 10 years experience. Most of the respondents $(91.1 \%)$ have university education.

\subsection{Descriptive Statistics and Correlation Analysis}

Table 3 displays the descriptive statistics (means and standard deviations) for each subscale of charismatic leadership. As shown in table 3 the mean score for charismatic leadership is $3.48(\mathrm{SD}=0.70)$, indicating that the managers have a moderate (closer to high) degree of charismatic leadership characteristics. Regarding the subscales of charismatic leadership, the results show that the unconventional behavior (UB) has achieved the highest mean (3.84) with $\mathrm{SD}=$ 0.84.This indicates that the employees see their managers apply original methods to achieve organizational goals; and managers' extraordinary behavior often surprises the company. On the other hand, the sensitivity to member needs $(\mathrm{SMN})$ scale scores the lowest mean (3.14) with $\mathrm{SD}=0.49$. This result reveals that the respondents' managers in this study cannot seriously express personal concern for the needs and feelings of other members in their companies.

Table 3. Mean Ranking of Charismatic Leadership Subscales

\begin{tabular}{|l|c|c|c|}
\hline \multicolumn{1}{|c|}{ Subscales } & Mean score & S.D & Rank \\
\hline Strategic vision and articulation (SVA) & 3.70 & 0.67 & 5 \\
\hline Personal risk (PR) & 3.30 & 0.77 & 3 \\
\hline Sensitivity to the environment (SE) & 3.42 & 0.75 & 2 \\
\hline Sensitivity to member needs (SMN) & 3.14 & 0.49 & 4 \\
\hline Unconventional behavior (UB) & 3.84 & 0.84 & 1 \\
\hline Charismatic leadership & 3.48 & 0.70 & \multicolumn{2}{|c}{} \\
\cline { 1 - 3 } & &
\end{tabular}

Moreover, as illustrated in Table 4, the total mean value for employee psychological engagement is 3.25 with $\mathrm{SD}=0.88$. Therefore, it is inferred that the engagement level of employee in travel companies is a moderate (closer to high) degree of engagement. "Absorption" (3.36) is the scale that achieved the highest mean score with $\mathrm{SD}=0.86$. This indicates that the employees in the sample are highly involved in their jobs. On the other hand, the scale with the lowest mean score is "vigor" (3.15) with $\mathrm{SD}=0.86$. 
This reveals that employees have a moderate level of energy to work for long periods; they are willing to invest effort at their jobs.

Table 4. Mean Ranking of Employee psychological engagement

\begin{tabular}{|l|c|c|c|}
\hline \multicolumn{1}{|c|}{ Subscales } & Mean score & S.D & Rank \\
\hline Vigor & $\mathbf{3 . 1 5}$ & $\mathbf{0 . 8 6}$ & $\mathbf{3}$ \\
\hline Dedication & $\mathbf{3 . 2 3}$ & $\mathbf{0 . 9 2}$ & $\mathbf{2}$ \\
\hline Absorption & $\mathbf{3 . 3 6}$ & $\mathbf{0 . 8 6}$ & $\mathbf{1}$ \\
\hline Emplovee psvchological engagement & $\mathbf{3 . 2 5}$ & $\mathbf{0 . 8 8}$ & \multicolumn{1}{|c}{} \\
\cline { 1 - 3 } & &
\end{tabular}

In addition, Table 5 illustrates the correlation matrix among all subscales of the study variables (charismatic leadership and employee psychological engagement). As expected, a high positive correlation between managers' charismatic leadership and employee psychological engagement in Egyptian travel companies is found $(\mathrm{r}=0.79)$. It is also observed that charismatic leadership is positively correlated to the three subscales of employee psychological engagement, ranging from $r=0.53$ with "vigor", $r=0.56$ with "dedication", to $\mathrm{r}=0.61$ with "absorption". Based on these results, if managers follow charismatic leadership behavior, the level of employee psychological engagement will be raised. In other words, these positive correlations indicate the possibility that the five subscales of charismatic leadership are good predictors of employee psychological engagement. It is also noted that "Sensitivity to member needs" (SMN) has the highest positive relationship with employee psychological engagement $(r=0.71)$. Therefore, the focus on the needs and feelings of other employees in the company and expressing personal concern to these need may influence and improve engagement.

Table 5. Descriptive Statistics and Inter-Correlations of Subscales Variables

\begin{tabular}{|l|l|l|l|l|l|l|l|l|l|l|}
\hline Dimension & 1 & 2 & 3 & 4 & 5 & 6 & 7 & 8 & 9 & 10 \\
\hline 1-(SVA) & - & & & & & & & & & \\
\hline 2-(PR) & 0.78 & - & & & & & & & & \\
\hline 3-(SE) & 0.83 & 0.75 & - & & & & & & & \\
\hline 4- (SMN) & 0.87 & 0.79 & 0.76 & - & & & & & & \\
\hline 5-(UB) & 0.81 & 0.86 & 0.77 & $0.82^{*}$ & - & & & & & \\
\hline 6- Charismatic & 0.86 & 0.91 & 0.84 & $0.78^{*}$ & 0.88 & - & & & & \\
\hline 7- Vigor & 0.42 & 0.53 & 0.49 & $0.55^{*}$ & 0.61 & $0.53^{*}$ & - & & & \\
\hline 8- Dedication & 0.32 & 0.43 & 0.64 & $0.46^{*}$ & 0.22 & $0.56^{*}$ & $0.70^{*}$ & - & & \\
\hline 9- Absorption & 0.71 & 0.62 & 0.58 & $0.62^{*}$ & 0.48 & $0.61^{*}$ & $0.78^{*}$ & 0.52 & - & \\
\hline 10- Employee & 0.52 & 0.62 & 0.69 & $0.71^{*}$ & 0.59 & $0.79^{*}$ & $0.81^{*}$ & 0.86 & 0.92 & - \\
\hline
\end{tabular}

Strategic vision and articulation (SVA), Personal risk (PR), Sensitivity to the environment (SE), Sensitivity to member needs (SMN), and Unconventional behavior $(U B)$

* The correlation is significant at the $(0.05)$ level

These findings concur with the recent studies by Salanova et al., (2011); Aryee and Walumbwa (2012); Vincent-Höper et al., (2012); Yuan et al., (2012); Ghadi et al., (2013) ; Gözükara and Şimsek( 2016) and Gigaba, (2015) which have concluded that the perceptions of charismatic leadership are significantly associated with increases in work engagement. The results also agree with the study of Strickland et al., (2007) which has investigated the relationship between work engagement and charismatic leadership. 
The results indicate that the charisma of leaders acts as a mediator and the most effective driver of higher work engagement. Additionally, the results of the current study are consistent with Bono and Judge (2003); Ul Haq et al., (2016); Zhu et al., (2009) who have found that followers of charismatic leaders have reported more self-concept engagement in their work since engagement is enhanced by the presence of a good relationship between leaders and employees. Finally, the above results support the first hypothesis which suggests that charismatic leadership behavior of managers will enhance employee psychological engagement in travel companies.

\subsection{Simple Linear Regression Analyses}

The study deployed a series of regressions to explore the predictive power of charismatic leadership on employee psychological engagement. According to the results obtained, charismatic leadership accounts for $54.9 \%$ of the variability (influence) in employee psychological engagement. The Adjusted R Square suggests that charismatic leadership accounts for $54.3 \%$ of the variability in employee psychological engagement. Generally, the model is moderately strong. However, it could be viewed as a strong model considering the fact that $54.9 \%$ is the variability contributed by only charismatic leadership. Moreover, the value of $r=0.79$ shows a fairly positive correlation $(r>0.05)$ between charismatic leadership and employee psychological engagement.

These results are congruent with the findings of a study by Roberson and Strickland (2010) which has concluded that charismatic leadership is considered predictive to determine employees' work engagement since it has accounted for $16 \%$ of the variance in work engagement. The above results also match the results of the study by Gözükara and Şimsek (2016) which has disclosed that employees admire, trust, and respect their charismatic leaders. Moreover, they are inspired by these leaders to persevere higher collective goals. Therefore, employees become more enthusiastic about the common vision created by the leaders and more willing to be part of it.

In addition to the above regression results, three separate simple regression analyses have been performed on the three subscales of employee psychological engagement as dependent variables and on the five subscales of managers' charismatic leadership as independent variables to identify to what extent the managers' charisma enhances every subscale of employee psychological engagement. As shown in Table 6, the results of the first regression indicates that the managers' charisma has a positive effect on vigor $(\mathrm{R}=0.53, \mathrm{p}<0.005)$. Charisma of managers could significantly explain $29.01 \%$ of the variances in the level of vigor behaviors of employees. Moreover, the model for predicting vigor based on charismatic leadership is significant $(\mathrm{F}=$ $31.013, \mathrm{p}<0.005)$. The results also reveal that charisma of managers has a positive effect on dedication $(\mathrm{R}=0.56, \mathrm{p}<0.005)$. This second regression model is also significant $(\mathrm{F}=35.148, \mathrm{p}<0.005)$, accounting for $31.14 \%$ of the variance of the dedication behaviors of the employees. According to the results, managers' charisma has positive effect on absorption $(\mathrm{R}=0.62, \mathrm{p}<0.005)$ and could significantly explain the variance in the absorption behaviors of the employees. 
Table 6. The Results of Managers' Charismatic Leadership Effects on Employee psychological engagement Subscales

\begin{tabular}{|l|c|c|c|}
\hline \multirow{2}{*}{$\begin{array}{l}\text { Independent variable } \\
\text { (Charismatic leadership) }\end{array}$} & \multicolumn{3}{|c|}{$\begin{array}{c}\text { Dependent variables } \\
\text { (Subscales of employee psychological } \\
\text { engagement) }\end{array}$} \\
\cline { 2 - 4 } & Vigor & Dedication & Absorption \\
\hline R & 0.53 & 0.56 & 0.62 \\
R2 & 29.013 & 31.148 & 34.237 \\
Adj. R2 & 0.209 & 0.312 & 0.372 \\
F & 31.013 & 35.148 & 17.534 \\
\hline
\end{tabular}

The results of the separate regression analyses reveal that charismatic leadership of managers in travel companies has significant positive effects on employee psychological engagement. Furthermore, the absorption subscale is the most associated subscale that could be predicted by charismatic leadership.

However, the results displayed in table 6 do not agree with Moss (2008) that found vigor rated as the most associated and the main subscale of engagement which could be predicted by charismatic leadership.

The results also confirm the study by Bono and Judge (2003) and Yukl (2006) which have concluded that charismatic leadership influences and motivates followers to adopt a common vision and energy (vigor) which instill in them a sense of fulfillment and challenge (absorption) and commitment (dedication). Consequently, engagement is enhanced. Moreover, the results of table 6 show an empirical evidence which is in line with the finding of previous research by Tims et al., (2011) who have predicted that charismatic leadership would indirectly enhance employees' work engagement levels of vigor, dedication, and absorption.

Generally speaking, the findings of this study show that employees' levels of engagement increase when there is a positive relationship between the employees and their direct supervisors (May et al., 2004 ;Gopal, 2006; Bakker and Schaufeli, 2008; Ghadi,2010). Thus, it is likely that charismatic leadership, as a motivational style of both the leader and the led, can play a positive role in generating higher levels of vigor, dedication, and absorption.

As made clear above, the second hypothesis suggesting that there is a predictive relationship between charismatic leadership style and employee psychological engagement in the tourism sector is supported by the results of the present study.

\section{Conclusion}

Many Management scholars and organizational researches have argued that charismatic leadership can be a key determinant of a number of individual and organizational performance (Flynn and Staw,2004;Hayibor et al., 2011). The present study adds to the charismatic leadership literature by providing empirical support of the relationships between charismatic leadership and employee psychological engagement in the tourism sector (travel companies). All hypothesized relationships are supported by the results obtained. 
The study highlights a number of valuable findings. The correlation and regression results indicate that charismatic leadership behavior is positively correlated with employee psychological engagement in travel companies. Moreover, the present study also shows that managers with high "sensitivity to member needs" (SMN) have effective impact on improving employee psychological engagement; respect and support of charismatic leader to their employees needs lead to enhanced employee psychological engagement. The results also reveal that charismatic leadership style is considered a moderately strong predictor of employee psychological engagement in the tourism sector (travel companies). Furthermore, the results demonstrate that "absorption" is the most associated subscale that could be predicted by charismatic leadership. In other words, charismatic leadership can raise a sense of fulfillment and challenge in the employee.

The current study presents some valuable results that have implications for both theoretical and practical research. As based on the previous results, the present study proposes some implementation and recommendation. First, travel companies should focus on employing, developing, and encouraging leaders to create high quality relationships with their employees. Second, according to the results, charismatic leaders enhance increasing energy and willingness of the employee to exert more efforts. Therefore, travel companies should provide relationship training as part of their leadership development or promotion. Third, supervisors should be encouraged to adopt charismatic leadership behavior to influence and improve employee psychological engagement. Fourth, subscales of charismatic leadership should be assed regularly to identify the factors which may affect employee psychological engagement. Fifth, managers should pay serious attention to "sensitivity to member needs $(\mathrm{SMN}) "$ since it is the main subscale influencing employee psychological engagement. In other words, if managers focus on the needs and feelings of the employees in the company and express personal concern to these need, this may improve engagement.

Although the present study adds a considerable contribution to the previous literature on this area, managers and researchers who wish to use the results to make specific strategic decisions should note several characteristics of the study that may limit its applicability. Charismatic behavior as well as employee psychological engagement have been rated by the same employees; this can lead to bias with regard to the associations between variables. Moreover, the technique used in the current study is restricted by the sample size. Therefore, it is recommended to enlarge the sample size in further studies. It is also valuable to choose other types of business in the tourism sector, such as hotels or airlines, in order to have a more comprehensive view. Another direction for future research would be to investigate the moderating role of other organizational factors in the relationship between the two variables of this study. More empirical explorations are recommended to examine the leadership engagement relationship from the perspectives of many leadership styles. 
Perhaps other types of leadership can also be helpful in understanding when, how, and what kinds of leadership behavior influence engagement. Finally, it would be interesting to examine the current findings in relation to different occupations and positions.

\section{References}

- Agyemang.C.and Ofei.S.(2013)Employee working engagement and organizational commitment : a comparative study of private and public sector organization in Ghana, European Journal of Business and Innovation Research, 1.1(4):.20-33.

-Albrecht, S. L. (2012) The influence of job, team and organizational level resources on employee well-being, engagement, commitment and extra-role performance. International Journal of Manpower, 33(7): 840-853.

- Alfes, K., Truss, C., Soane, E. C., Rees, C. and Gatenby, M. (2010). Creating an engaged workforce: Findings from Kingston Employee psychological engagement Consurtium Project. CIPD Research Report.

-Amabile, T.M., Schatzel, E.A., Moneta, G.B. and Kramer, S.J. (2004), Leader behaviors and the work environment for creativity: Perceived leader support, the Leadership Quarterly, 15(.1):.5-32..

-Antonakis ,J.,Fenley, M. and Liechti,S.(2011) Can charismatic be taught? Tests of two interventions, Academy of Management Learning and Education, Academy of Management Learning and Education,. 10, (3): 374-396.

- Ariani,D.,(2013) The relationship between employee psychological engagement, organizational citizenship behavior, and counterproductive work behavior, International Journal of Business Administration, 4, ( 2) :46-56.

-Aryee, S., and Walumbwa, F. (2012). Transformational leadership, innovative behavior, and task performance: Test of mediation and moderation processes. Human Performance, 25: 1-25.

-Babaita ,C., Sipos,G., Ispas,A.,and, Nagy,N.(2013) Leadership style and culture for innovation in hotel industry, Proceedings of the 5th WSEAS International Conference on Economy and Management Transformation (Volume II) .

- Bakker A. B and Schaufeli WB (2008) Positive organizational behavior: engaged employees in flourishing organizations, Journal of Organizational Behavior 29: 147-54.

-Bakker, A. B. (2009). Building engagement in the workplace. In R. J. Burke and C. L. Cooper (Eds.), The peak performing organization :. 50-72. Abingdon, UK: Routledge.

- Bakker, A. B., and Bal, P. M. (2010). Weekly work engagement and performance: A study among starting teachers. Journal of Occupational and Organizational Psychology, 83:189-206.

-Bakker, A. B., Schaufeli, W. B., Leiter, M. P., and Taris, T. W. (2008). Work engagement: An emerging concept in occupational health psychology. Work and Stress, 22: 187-200. 
- Bakker, Arnold B., Albrecht, Simon L. and Leiter, Michael P.(2011) 'Key questions regarding work engagement', European Journal of Work and Organizational Psychology, 20: 1, 4-28.

- Bakker,A. and Demerouti,E.(2008) Towards a model of work engagement, Career Development International , 13 ( 3) : 209-223.

- Basadur, M. (2004), Leading others to think innovatively together: Creative leadership, The Leadership Quarterly, 15(1).103-121.

- Bates, S. (2004) Getting engaged, HR Magazine, 49 ( 2): 44-51.

-Baumruk, R. (2004)The missing link: the role of employee psychological engagement in business success, Workspan, 47: 48-52.

- Birchfield,R. (2000)Creating Charismatic Leaders, Management, 47(5) : 30-31

- Bono JE and Judge TA (2003) Self-Concordance at work: Toward understanding the motivational effects of transformational leaders, Academy of Management Journal 46: 554-571.

- Boyne ,S.(2012) Leadership and motivation in hospitality, PH thesis, Bournemouth University .

-Bryman, A. (2004), Qualitative research on leadership: A critical but appreciative review, The Leadership Quarterly.15(.6):729-776.

- Carasco-Saul1,M.,, Kim1,W., and Kim1,T.(2015) Leadership and Employee psychological engagement: Proposing Research Agendas Through a Review of Literature , Human Resource Development Review, 14(1): 38-63.

- Catlette, B., and Hadden, R. (2001). Contented cows give better milk: the plain truth about employee relations and your bottom line. Germantown: Saltillo Publishing.

- Chaudhary,S., and Kumar,A.(2014 ) A study on Employee psychological engagement with respect to Hotels in Bangalore, Research Scholar Bharthiar University available at : apjor.com/files/1448216902.docx (Accessed on 23 March 2017) .

- Chiang, C.-F., and Jang, S.( 2008) The Antecedents and Consequences of Psychological Empowerment: The Case of Taiwan's Hotel Companies. Journal of Hospitality and Tourism Research, 32 (1): 40-61.

- Christian, M.S., Garza, A.S., and Slaughter, J.E. (2011). Work Engagement: A Quantitative Review a Test of Its Relations with Task and Contextual Performance. Personnel Psychology, 64(1): 89-136.

- Christoffer, P.( 2004) Hudson-Driving Performance and Retention Through Employee psychological engagement - Corporate leadership Council, Employee psychological engagement Survey.

- Cicero,L and Pierro,A.,(2007) Charismatic leadership and organizational outcomes: The mediating role of employees' work-group identification, International Journal of Psychology. 42 (5), 297-306.

-Clark, R. A., Hartline, M. D., and Jones, K. C.( 2009) The Effects of Leadership Style on Hotel Employees' Commitment to Service Quality. Cornell Hospitality Quarterly, 50 (2): 209-231. 
- Conger, J. A., and Kunungo, R.N. (1987). Towards a behavioral theory of charismatic leadership in organizational setting. Academy of Management Review, 12: 637-47.

- Conger, J. A. (1989). The charismatic leader: Behind the mystique of exceptional leadership. San Francisco, CA: Jossey-Bass.

-Conger JA, and Kanungo RN. (1992)Perceived behavioral attributes of charismatic leadership. Canadian Journal of Behavioral Science, 24: 86-102.

- Conger, J.A. and Kanungo, R.N. (1994) Charismatic leadership in organizations: Perceived behavioral attributes and their measurement, Journal of Organizational Behavior, 15(.5):439-452.

- Conger JA, Kanungo RN, Menon ST, and Mathur P. (1997) Measuring charisma: dimensionality and validity of the Conger \pm Kanungo scale of charismatic leadership. Canadian Journal of Administrative Sciences, 14(3): 290-302.

- Conger, J.A. (1998), Qualitative research as the cornerstone methodology for understanding leadership. The Leadership Quarterly, 9(1):107-121.

- Conger, J. A., and Kanungo, R. N. (1998) Charismatic leadership in organizations. Thousand Oaks, CA: Sage.

- Conger, J. A. (2000). Charismatic leadership and follower effects. Journal of organizational behavior :747-767.

- Conger, J.A, Kanungo, R.N and Menon, A.S. (2000). Charismatic leadership and followers effects. Journal of Organizational Behavior, 20: 747767.

- Czarnowsky, M. (2008) Learning's role in employee psychological engagement: An ASTD research study, Alexandria, VA, American Society for Training and Development.

- Deery, M. ( 2008) Talent management, work-life balance and retention strategies. International Journal of Contemporary Hospitality Management, 20 (7): 792-806.

- Egyptian travel agents association (2016).the Egyptian travel agents guide 2015-2016.Egyptian Tourism Federationand Association(33th edition) .

- Ehrhart, M. G., and Klein, K. J. (2001). Predicting followers' preferences for charismatic leadership: the influence of follower values and personality. The Leadership Quarterly, 12: 153-179.

- Findiklıa,M,Yozgat,U. and Procedia, b. (2012)A qualitative analysis of charismatic leadership in creative teams: the case of Turkish TV series directors - Social and Behavioral Sciences 41 : 227 - 236.

- Fletcher, L. and Robinson,D.,( 2014) Measuring and Understanding Employee psychological engagement: available at : https://research.aston.ac.uk/portal/en/researchoutput/measuring-andunderstanding-employee-engagement(aaa4ed0c-7896-4235-8cc98e6a487bfb06).html (Acessed on 23 April 2017).

- Flynn,J., and Staw ,B.(2004) Lend me your wallets :the effects of charismatic leadership on external support for an organization, strategic management journal, 25:309-330. 
Forsstrom,C.(2012)The charismatic CEO: a study on charismatic leadership in high performing businesses ,Copenhagen business school .Available at: studenttheses.cbs.dk/bitstream/handle/.../casper_forsstroem.pdf?...1(Accessed on 30 April2017).

- George,G., and Joseph†,B.( 2017 ) A Study on the Relationship between Employee psychological engagement and Organizational Citizenship with Reference to Employees Working in Travel Organizations ,Atna Journal of Tourism Studies ,10(2):33-44.

-Ghadi, M., Fernando, M. and Caputi, P. (2010). Transformational leadership, workplace engagement and the mediating influence of meaningful work: Building a conceptual framework. Australian New Zealand Academy of Management Annual Conference : 1-15.

- Ghadi, M. Y., Fernando, M., and Caputi, P. (2013). Transformational leadership and work engagement: The mediating effect of meaning in work. Leadership and Organization Development Journal, 34(6), 1-34.

- Gigaba, M. (2015) The impact of leadership style on employee psychological engagement in the platinum mining sector in South Africa .Gorden institute of business science .University of Pietoria. Available at: https://repository.up.ac.za/bitstream/handle/2263/52394/Gigaba_Impact_2016. pdf? sequence=11(Acessed on 24 April2017).

-Gopal A (2006) Worker disengagement continues to cost Singapore, The Gallup Management Journal, online, available at: http://gmj.gallup.com/content/22720/Worker-Disengagement-Continues- CostSingapore.aspx (accessed on 3 August 2017).

- Gözükara1.I. and Şimsek, Ö .(2016)Role of Leadership in Employees' Work Engagement: Organizational Identification and Job Autonomy, International Journal of Business and Management; 11( 1):72-84.

- Gupta, M., Ganguli, S., and Ponnam, A. (2015) Factors affecting employee psychological engagement in India: A study of off shoring of financial services. The Qualitative Report, 20(4): 498-515.

-Halbesleben, J. R. B., and Wheeler, A. R. (2008). The relative role of engagement and embeddedness in predicting job performance and turnover intention. Work and Stress, 22:, 242-256.

- Hall, R. (2008). Applied Social Research: Planning, designing and conducting real-world research. Malaysia: Palgrave Macmillan.

-Hayibor,S., Agle,B., Sears.G, Sonnenfeld ,J.and Ward.A,(2011) Value Congruence and Charismatic Leadership in CEO-Top Manager Relationships: An Empirical Investigation, Journal of Business Ethics ,102:237-254.

- House, R. J. (1997). A 1976 theory of charismatic leadership. In J. G. Hunt and L. L. Larson (Eds.), Leadership: The cutting edge :189-207. Carbondale, IL: Southern Illinois University.

-House, R. J. (1999) Weber and the Neo-charismatic Leadership Paradigm: A Response to Beyer. The Leadership Quarterly, 10(4): 563-574.

- House, R. J., and Howell, J. M. (1992). Personality and charismatic leadership. The Leadership Quarterly, 3, 81-108. 
- House, R. J., and Shamir, B. (1993). Toward the integration of transformational, charismatic, and visionary theories. In M. Chemers and R. Ayman (Eds.), Leadership theory and research perspectivesand directions : 577-594. Orlando, FL: Academic Press.

-Howell, J. M., and Shamir, B. (2005). The role of followers in the charismatic leadership process: Relationship and their consequences. Academy of Management Review, 30: 96-112.

-Hughes,R.L. and Ginnett,R.C.(2003) Leadership: Enhancing the lessons of experience..New York:Irwin McGraw-Hill..

- Jacobsen, C., and House, R. J. (2001). Dynamics of charismatic leadership: A process theory, simulation model, and tests.The Leadership Quarterly, 12: 75-112.

Journal of Behavioral Science, 24: 86-102.

- Kahn, W.A. (1990). Psychological Conditions of Personal Engagement and Disengagement of Work. Academy of Management Journal, 33(4), 692724.

- Kaul,N.,(2013)Charismatic leadership blessing or curse?, International Journal on Leadership, $1: 11-17$.

- Kenexa (2008) Engaging The Employee: A Kenexa Research Institute ,World Trends Report., Kenexa Research Institute.

- Khurana, R.(2002) Searching for a Corporate Savior: The Irrational Quest for Charismatic CEOs. Princeton: Princeton University Press.

Koene,B.A.S. and Vogelaar,A.L.W.(2002) Leadership effects on organizational climate and financial performance: Local leadership effect in chain organizations.The Leadership Quarterly, 13 :193-215.

-Koppula, R. (2008) Examining the relationship between transformational leadership and engagement. Master's thesis. San Jose State University.

- Kuruüzüm, A., Çetin, E. I., and Irmak, S.(2009) Path analysis of organizational commitment, job involvement and job satisfaction in Turkish hospitality industry. Tourism Review, 64 (1): 4-16 .

-Lockwood, N. R. (2007) Leveraging employee psychological engagement for competitive advantage: HR's strategic role. Alexandria: Society for Human Resource Management.

- Lolitha,C.,and Johnson,J.,( 2014 ) Employee psychological engagement and organizational commitment among It sector employees in Kerala, Mahatma Gandhi University, Twelfth AIMS International Conference on Management.

-Luthans F, and Peterson SJ (2002) 'Employee psychological engagement and manager self- efficacy: implications for managerial effectiveness and development', Journal of Management Development, 21(5): 376-387.

- May DR, Gilson, RL and Harter LM (2004) The psychological conditions of meaningfulness, safety and availability and the engagement of the human spirit at work, Journal of Occupational and Organizational Psychology 77: 1137.

- Meredith , Babcock Elaine; Oriel, and Strickland J;. (2010) The relationship between charismatic leadership, work engagement and 
organizational citizenship behaviors. The journal of psychology: Interdisciplinary and applied, 144(3): 313-326.

- Moss, S. (2008). Cultivating the regulatory focus of followers to amplify their sensitivity to transformational leadership. Journal of Leadership and Organizational Studies, 15: 241-259.

- Nandal ,V. and Krishnam ,V,(2000) Charismatic leadership and self efficacy: importance of role clarity, management and labour studies ,25(4)231-243.

- Ndethiu ,E.(2014) The effects of leadership styles on employee psychological engagement in an international bank with substantial operations in Kenya ,Master thesis ,United States international University .

- Øgaard, T., Marnburg, E., and Larsen, S. ( 2008) Perceptions of organizational structure in the hospitality industry: Consequences for commitment, job satisfaction and perceived performance. Tourism Management, 29 (4): 661-671.

-Paulsen, N., Maldonado, D., Callan, V. J. and Ayoko, O. (2009), Charismatic leadership, change and innovation in an RandD organization, Journal of Organizational Change Management, 22(5):511-523.

-Poskas,D., Messer ,C, HorntvedtJ, and E. VitcendaM,(2013) Exploring the Impact of Charismatic Leaders in Communities, Leaders' guide for the story of Sanluis instructional case study, University of Minnesota, Extension Center for Community vitality:231-243.

- Poskas, D. A.T, and Messer, C. C. (2015). Investigating Leadership Applications in Tourism: A Case Study of Leadership in Community Tourism. Journal of Teaching in Travel and Tourism, 15(2): 186-198.

- Purcell, J (2012)The limits and possibilities of employee psychological engagement, Warwick papers in industrial relations, number 96, Industrial Relations Research Unit, University of Warwick,,Available at: https://www2.warwick.ac.uk/fac/soc/wbs/research/irru/wpir/wpir_96.pdf(Acess ed on 24 March 2017).

- Raelin, A. (2003) The Myth of Charismatic Leaders. T+D (March 2003), 47-51.

- Rich, B.L., Lepine, J.A., and Crawford, E.R. (2010). Job Engagement: Antecedents and Effects on Job Performance. Academy of Management Journal, 53(3): 617-635.

- Richman, A. (2006)Everyone wants an engaged workforce how can you create it?, Workspan, 49: 36-9.

-Ricketts, K. (2009). Studying leadership within successful rural communities in a Southeastern state: A qualitative analysis. Journal of Leadership Education, 7(3): 230-245.

- Roberson ,M.and Strickland ,O.(2010)The Relationship Between Charismatic Leadership, Work Engagement, and Organizational Citizenship Behaviors, The Journal of Psychology, 144(3):313-326.

- Rothbard, N.P. (2001)Enriching or depleting? The dynamics of engagement in work and family roles, Administrative Science Quarterly,. 46: 655-84. 
-Sadiqe, M. (2014) Employee psychological engagement in hospitality industry in India: An overview. Global Journal of Finance and Management. 6(4): 375-378.

- Saks,A.( 2006) Antecedents and consequences of employee psychological engagement, Journal of Managerial Psychology, 21 ( 7): 600-619.

- Salanova, M., Agut, S., and Peiro, J. M. (2005). Linking organizational resources and work engagement to employee performance and customer loyalty: The mediation of service climate. Journal of Applied Psychology, 90: 1217-1227.

- Salanova, M., Lorente, L., Chambel, M. J., and Martinez, I. M. (2011). Linking transformational leadership to nurses' extra-role performance: The mediating role of self-efficacy and work engagement. Journal of Advanced Nursing, 67(10): 2256-2266.

- Schaufeli, W. B., and Bakker, A. B., (2003). UWES (Utrecht Work Engagement Scale) Preliminary Manual. Occupational Health Psychology Unit, Utrecht University. The Netherlands.

- Schaufeli.W, and Bakker,A. (2004) Job demands, job resources, and their relationship with burnout and engagement: a multi-sample study, Journal of Organizational Behavior . 25: 293-315.

- Schaufeli, W. B., and Bakker, A. B. (2010). Defining and measuring work engagement: Bringing clarity to the concept. In A. B. Bakker andM. P. Leiter (Eds.), Work engagement: A handbook of essential theory and research : 1024. New York: Psychology Press.

- Schaufeli, W. B., Salanova, M., González-Romá, V., and Bakker, A. B. (2002) The measurement of engagement and burnout: A two sample confirmatory factor analytic approach. Journal of Happiness Studies, 3: 71-92.

-Shalley, C.E. and Gilson, L.L. (2004), What leaders need to know: a review of social and contextual factors that can foster or hinder creativity, The Leadership Quarterly, 15(1):.33-53.

- Shamir B, House R, Arthur MB. (1993) The motivational effects of charismatic leadership: a self-concept based theory. Organizational Science, 4(4): 577-594.

- Shamir, B.Z. (1998), Correlates of charismatic leader evidence from Korea, Academy of Management Journal, 46 (6): 703-714.

-Shao, Z., Feng, Y., Hu, Q. and Liu, Y. (2009), A conceptual model for studying the influence of charismatic leadership on ERP implementation lifecycle, Proceedings of the 42nd Hawaii International Conference on System Sciences, 5-8 January:1-9.

- Sharmila, J.J.V. (2013). Employee psychological engagement - An approach to organizational excellence. International Journal of Social Science and Interdisciplinary Research, 2(5): 111-117.

-Smith ,R., and Markwick ,C(2009) Employee psychological engagement A review of current thinking, Report 469,Institute for employment. University of Sussex Campus, Brighton .

- Soane, E., Truss, C., Alfes, K., Shantz, A., Rees, C., and Gatenby, M. (2012). Development and application of a new measure of employee 
psychological engagement: the ISA Engagement Scale. Human Resource Development International, 15(5): 529-547.

- Strickland, O., Babcock, M., Gomes, L., E., Muh, V., and Secarea, A. (2007). The relationship between leader charisma, work engagement, and turnover intentions. Poster session presented at the annual Western Psychological Association Sasttle, Washington,.

-Susan, E. and Ellen, A. (2008). A qualitative analysis of charismatic leadership in creative teams: The case of television directors, The Leadership Quarterly, 19(.3):.335-352.

-Susskind, A. M., Borchgrevink, C. P., Brymer, R. A., and Kacmar, K. M., (2000a) Customer Service Behavior and Attitudes among Hotel Managers: A Look at Perceived Support Functions, Standards for Service, and Service Process Outcomes. Journal of Hospitality and Tourism Research, 24 (3): 373397.

- Susskind, A. M., Borchgrevink, C. P., Michele Kacmar, K., and Brymer, R. A. (2000b) Customer service employees' behavioral intentions and attitudes: an examination of construct validity and a path model. International Journal of Hospitality Management, 19 (1): 53-77.

-Takala, T. (2007). Charismatic Leadership and Ethics from Gender Perspective, available at: http://ejbo.jyu.fi/articles/0901_6.html(accessed on 12 April ,2017).

-Testa, M. R. ( 2004) Cultural similarity and service leadership: a look at the cruise industry. Managing Service Quality, 14 (5): 402 - 413.

-Tilstra,D.(2010)Charismatic leaders as team leaders :an evaluation focused on pastoral leadership, Journal of Religious Leadership, 9( 2):27-52.

- Tims, M., Bakker, A. B., and Xanthopoulou, D. (2011). Do transformational leaders enhance their followers' daily work engagement? The Leadership Quarterly, 22, 121-131.

-Tosi,H.L.,Misangyi,V.F.,Fanelli,A.,Waldman,D.A. and Yammarino,F.J. (2004) CEO charisma, compensation and firm performance. The Leadership Quarterly, 15:405-421.

-Tsai, C.-W. (2008) Leadership style and employee's job satisfaction in international tourist hotels. In Woodside, A. (Ed.), Advances in Culture, Tourism and Hospitality Research, 2 : 293-332

- Tutuncu, O., and Kozak, M.(2007) An Investigation of Factors Affecting Job Satisfaction. International Journal of Hospitality and Tourism Administration, 8 (1): 1-19.

-Ul Haq,M., Farooqi,Y. and Ahmad,M.(2016) The Relationship between Charismatic Leadership, WorkEngagement, and Organizational Citizenship Behaviors and Job Responsibilities ,Journal of Marketing and Consumer Research ,21: 60-66.

- Vincent-Hoper, S., Muser, C., and Janneck, M. (2012). Transformational leadership, work engagement, and occupational success. Career Development International, 17: 663-682. 
-Waldman,D.A. and Javidan,M.(2004) Charismatic leadership at the strategic level: A new application of upper echelons theory.The LeadershipQuarterly,15:.355-381.

- Weber, M. (1947). Max Weber: The theory of social and economic organization. T. Parsons (Ed.) and A.M. Henderson (Trans.) New York: The Free Press.

- Xanthopoulou, D., Bakker, A. B., Demerouti, E., and Schaufeli, W. B. (2009). Reciprocal relationships between job resources, personal resources, and work engagement. Journal of Vocational Behavior, 74: 235-244.

-Xu, J., and Thomas, H. (2011). How can leaders achieve high employee psychological engagement? Leadership and Organization Development Journal, 32:399-416.

- Yang, J.-T.,( 2010) Antecedents and consequences of job satisfaction in the hotel industry. International Journal of Hospitality Management, 29 (4): 609-619.

-Yorges, S. L., Weiss, H. M., and Strickland, O. J. (1999). The effect of leader outcomes on influence, attributions, and perceptions of charisma. Journal of Applied Psychology,: 84(3):428-36.

- Yuan, B. J., Lin, M. B., Shieh, J.-H., and Li, K.-P. (2012). Transforming employee psychological engagement into long-term customer relationships: Evidence from information technology salespeople in Taiwan. Social Behavior and Personality, 40: 1549-1553.

-Yukl GA (2006) Leadership In Organizations, Upper Saddle River, NJ: Pearson Prentice Hall.

- Zainol.S.,Hussin .,S.,and Othman .M. (2016) Determinants of Employee psychological engagement in Hotel Industry in Malaysia. A Theoretical Model, International Journal of Academic Research in Accounting, Finance and Management Sciences 6(3): 1-9

- Zehir,C., Erdogan,E., and Basar ,D.(2011) The relationship among charismatic leadership, ethical climate, job satisfaction and organizational commitment in companies, Journal of Global Strategic Management , 5 ( 2 ) $: 49-59$.

- Zhu, W., Avolio, B. J., and Walumbwa, F. O. (2009). Moderating role of follower characteristics with transformational leadership and follower work engagement. Group and Organization Management, 34: 590-619.

- Zikmund, W.G., Babin, B., Car, J. and Griffin, M. (2013) Business research methods. Ninth edition, International edition, Published Australia: South-Western. 


\section{Appendix}

\section{A-Subscales of charismatic leadership}

\section{The Study Questionnaire}

Please measure the degree of your manager leadership attitudes from $1=$ Strongly Disagree, 2= Disagree, 3= Neutral, 4= Agree and 5= Strongly Agree

\begin{tabular}{|c|c|c|c|c|}
\hline Subscales & 1 & 3 & 4 & 5 \\
\hline \multicolumn{5}{|l|}{ strategic vision and articulation (SVA) } \\
\hline \multicolumn{5}{|l|}{ 1-Has vision; often brings up ideas about possibilities for the future. } \\
\hline \multicolumn{5}{|l|}{ 2-Provides inspiring strategic and organizational goals. } \\
\hline \multicolumn{5}{|l|}{ 3-Consistently generates new ideas for the future of the organization } \\
\hline \multicolumn{5}{|l|}{ 4-Entrepreneurial; seizes new opportunities in order to achieve goals } \\
\hline \multicolumn{5}{|l|}{$\begin{array}{l}\text { 5-Readily recognizes new environmental opportunities ( favorable physical and } \\
\text { social conditions) that may facilitate achievement or organizational objectives. }\end{array}$} \\
\hline \multicolumn{5}{|l|}{$\begin{array}{l}\text { 6-Inspirational; able to motivate by articulating effectively the importance of } \\
\text { what organizational members are doing. }\end{array}$} \\
\hline \multicolumn{5}{|l|}{ 7-Exciting public speaker. } \\
\hline \multicolumn{5}{|l|}{ Personal risk $(P R)$} \\
\hline \multicolumn{5}{|l|}{$\begin{array}{l}\text { 1-In pursuing organizational objectives, engages in activities involving } \\
\text { considerable personal risk. }\end{array}$} \\
\hline \multicolumn{5}{|l|}{ 2-Takes high personal risks for the sake of the organization. } \\
\hline \multicolumn{5}{|l|}{$\begin{array}{r}\text { 3-Often incurs high personal cost for the good of the organization. } \\
\text { Sensitivity to the environment (SE) }\end{array}$} \\
\hline Sensitivity to the environment (SE) & & & & \\
\hline \multicolumn{5}{|l|}{$\begin{array}{l}\text { 1-Readily recognizes constraints in the physical environment (technological } \\
\text { limitations, lack of resources, etc.) that may stand in the way of achieving } \\
\text { organizational objectives. }\end{array}$} \\
\hline \multicolumn{5}{|l|}{$\begin{array}{l}\text { 2-Readily recognizes constraints in the organization's social and cultural } \\
\text { environment (cultural norms, lack of grass roots support, etc.) that may stand in } \\
\text { the way of achieving organizational objectives. }\end{array}$} \\
\hline \multicolumn{5}{|l|}{ 3-Recognizes the limitations of other members of the organization. } \\
\hline \multicolumn{5}{|l|}{ 4-Recognizes the abilities and skills of other members of the organization. } \\
\hline \multicolumn{5}{|l|}{ Sensitivity to member needs (SMN) } \\
\hline \multicolumn{5}{|l|}{$\begin{array}{l}\text { 1-Shows sensitivity for the needs and feelings of the other members in the } \\
\text { organization. }\end{array}$} \\
\hline \multicolumn{5}{|l|}{ 2-Influences others by developing mutual liking and respect. } \\
\hline \multicolumn{5}{|l|}{$\begin{array}{l}\text { 3-Often expresses personal concern for the needs and feelings of other members } \\
\text { in the organization. }\end{array}$} \\
\hline \multicolumn{5}{|l|}{ Unconventional behavior $(\mathrm{UB})$} \\
\hline \multicolumn{5}{|l|}{ 1-Engages in unconventional behavior in order to achieve organizational goals. } \\
\hline \multicolumn{5}{|l|}{ 2-Use non-traditional means to achieve organizational goals. } \\
\hline $\begin{array}{l}\text { 3-Often exhibits very unique behavior that surprises other members of the } \\
\text { organization. }\end{array}$ & & & & \\
\hline
\end{tabular}

\section{B-Subscales of Employee engagement}

Please judge how frequently each statement fits you as $1=$ Strongly

Disagree, 2= Disagree, 3= Neutral, 4= Agree and 5= Strongly Agree

\begin{tabular}{|cc|c|c|c|c|c|}
\hline Subscales & 1 & 2 & 3 & 4 & 5 \\
\hline \multicolumn{2}{|c|}{ Vigor } & & & & \\
\hline
\end{tabular}


